\title{
Molecular and Cellular Pediatrics
}

\author{
Klaus-Michael Debatin
}

\section{Editorial}

On behalf of the Editorial Board, I cordially welcome all physicians and scientists dedicated to pediatrics to contribute to the new journal Molecular and Cellular Pediatrics.

Although numerous high-ranking pediatric journals cover the field of clinical research, to date, scientific findings in cellular/molecular as well as translational research in pediatrics are mostly published in specialized journals of the respective area. In order to present a platform that covers all areas of basic and translational research related to pediatrics, the German Society of Pediatrics and Adolescent Medicine (Deutsche Gesellschaft für Kinder- und Jugendmedizin e.V., DGKJ) and Springer Verlag are happy to announce now the launching of this new international, open-access journal. I am confident that this journal will provide the appropriate forum for basic research-oriented pediatrics, a field that to date has remained largely neglected.

Molecular and Cellular Pediatrics is an international and interdisciplinary open-access journal publishing peerreviewed articles on innovative research in pediatrics. All articles are made freely and permanently accessible online immediately upon publication.

The focus and the topics of this journal cover research areas relevant to pediatrics including rare diseases, genetic diseases, gene therapy, cardiology, endocrinology, gastroenterology, genetics, immunology, infectiology, nephrology, neurology, oncology and hematology, pneumology, metabolism, neonatology, and translational medicine in pediatrics.

Molecular and Cellular Pediatrics is dedicated to promoting the exchange and discussion of current molecular and cellular concepts in pediatric medicine. This includes frontline reviews of the latest developments, original research articles, and a forum for discussion of pathophysiological concepts.

Molecular and Cellular Pediatrics is an official journal of the German Society of Pediatrics and Adolescent

Correspondence: klaus-michael.debatin@uniklinik-ulm.de

Klinik für Kinder- und Jugendmedizin, Universitätsklinikum Ulm, Eythstr. 24, Ulm 89075, Germany

\section{Springer}

(c) 2014 Debatin; licensee Springer. This is an Open Access article distributed under the terms of the Creative Commons Attribution License (http://creativecommons.org/licenses/by/4.0), which permits unrestricted use, distribution, and reproduction in any medium, provided the original work is properly cited.
Medicine (DGKJ). We thank Springer for making the launch of our journal possible. In addition, I especially thank our internationally recognized Editorial Board (http://www.molcellped.com), whose members have volunteered to assist in this undertaking despite their many commitments. With their expertise covering all the abovementioned fields of research, a timely and competent review process is ensured. Thus, together with the professionals at Springer, we guarantee that your work is published with appreciation. I would like to encourage experienced as well as young colleagues to submit papers to Molecular and Cellular Pediatrics.

Received: 22 July 2014 Accepted: 22 July 2014

Published: 4 September 2014

doi:10.1186/s40348-014-0004-0

Cite this article as: Debatin: Molecular and Cellular Pediatrics. Molecular and Cellular Pediatrics 2014 1:4.
Submit your manuscript to a SpringerOpen ${ }^{\circ}$ journal and benefit from:

- Convenient online submission

- Rigorous peer review

- Immediate publication on acceptance

- Open access: articles freely available online

- High visibility within the field

- Retaining the copyright to your article

Submit your next manuscript at $\boldsymbol{s p r i n g e r o p e n . c o m ~}$ 